\title{
Water balance in a neotropical forest catchment of southeastern Brazil
}

\author{
Carlos R. Mello ${ }^{1 *}$, Léo F. Ávila ${ }^{1}$, Henry Lin ${ }^{2,3,4}$, Marcela C.N.S. Terra ${ }^{1}$, Nick A.
}

$$
\text { Chappell }{ }^{5}
$$

${ }^{1}$ Soil and Water Engineering, Engineering Department, Federal University of Lavras, MG, Brazil, 37200000, C.P. 3037, *Corresponding author. E-mail: crmello@deg.ufla.br

${ }^{2}$ Department of Ecosystem Science and Management, College Agricultural Science, Pennsylvania State University, State College, Pennsylvania, USA.

${ }^{3}$ State Key Laboratory of Loess and Quaternary Geology, Institute of Earth Environment, Chinese Academy of Sciences, Xi'an 710061, China

${ }^{4}$ State Key Laboratory of Eco-hydraulic Engineering in Arid Area, Xi'an University of Technology, Xi'an, 710048, China

${ }^{5}$ Lancaster Environmental Centre, Lancaster University, Lancaster, UK.

\section{Abstract}

Brazilian Atlantic Forest is recognized by the UNESCO as one of the most important biosphere reserve on the planet but is threatened by extinction. The objective of this study was to analyze the main components of the water balance in an Atlantic Forest (Neotropical Forest) catchment in Mantiqueira Range, Brazil, which is a Tropical Montane Cloud Forest. The main focuses were to analyze baseflow, evapotranspiration, soil moisture, and canopy rainfall interception to understand the hydrologic dynamics in this specially important montane forest. On average from the two studied hydrological years (2009/2010 and 2010/2011), evapotranspiration (ET), streamflow (SF), and water storage in the catchment in the end of hydrological year corresponded, respectively, to $50 \%, 34.8 \%$ and $15.2 \%$ of total gross precipitation $(\mathrm{P})$. On average, baseflow 
corresponded to $73.5 \%$ of SF. The estimated potential groundwater recharge during the wet seasons was $403.8 \mathrm{~mm}$ (21.7\% of P observed in the wet season) and $710.5 \mathrm{~mm}(28.5 \%$ of P observed in the wet season), respectively, for 2009/2010 and 2010/2011 hydrological years, showing that the catchment is able to store groundwater to provide the maintenance of the streamflow during recession phase via baseflow as well as during drought periods. Therefore, the baseflow is important in mountainous catchments in the tropical regions to provide important ecological functions, mainly as freshwater reserve.

Keywords: Baseflow, Evapotranspiration, Tropical Montane Forest, Soil Moisture.

\section{Introduction}

The Brazilian Atlantic Forest has been recognized by the UNESCO as one of the most important biosphere reserve on the planet due to its endemic species and hydrological relevance. This ecosystem, which originally covered 100 million hectares ( $16 \%$ of the country's area), now covers less than 7 million hectares, mostly restricted to the mountainous regions of Southeastern Brazil (Galindo-Leal and Câmara 2003; Tabarelli et al. 2010). Due to human beings interventions, this kind of forest has been referred as Neotropical Forest remnant (Terra et al. 2017). Despite the environmental and ecological importance of the Neotropical Forests for the country, there are few studies detailing their hydrological functioning, especially regarding baseflow and its possible mechanisms and connections with other water balance components.

In tropical mountainous regions, the Neotropical Forest sites are known as Tropical Montane Cloud Forest (TMCF), and they are further classified in accordance 
47 with its elevation and dominant species. TMCF sites have a complex interaction between

forest canopy, weather, soils, and streamflow, which has led to controversies regarding its hydrological role in tropical regions, mainly in the context of the baseflow behavior. To overcome these controversies, some studies have been carried out towards detailing the water balance elements ( i.e., streamflow, canopy rainfall interception, soil moisture, evapotranspiration. and their relationships) around the world, but they are scarce in the Brazilian Atlantic Forest. In this regard, the availability of datasets based on a continuous monitoring of streamflow, weather, soil moisture, and throughfall, covering both the ascension and recession of complete hydrological years, is imperative. One of these few studies was that done by Salemi et al. (2013), which was based on meteorological and streamflow monitoring and a few rain-gauges for throughfall measurement during a hydrological year. However, neither evapotranspiration nor soil moisture were studied.

In other sites around the world, Muñoz-Villers et al. (2012) studied the water balance components of two TMCF sites in the central region of Mexico. They stated that these catchments are laid on a bedrock and saprolite interfaces with good permeability, which indicates reasonable capacity for groundwater storage along with relevant interrelationship among the components of water balance. Fleischbein et al. (2005) and Fleischbein et al. (2006) also analyzed the water balance in a TMCF of the Equatorial Andes. They found that the canopy had a significant role in the protection of soils in terms of the overland flow generation, since the canopy reduces the impact of rainfall intensity over the ground, allowing greater opportunity for water infiltration. Wiekenkamp et al. (2016) studied the role of the soils in the hydrology of a TMCF site in Germany. They concluded that soils with mature native forest have shown high porosity and pores 
interconnected that can generate preferential flows. These features lead to a higher infiltration capacity as well as greater natural streamflow regulation.

Muñoz-Villers et al. (2016) provided an important contribution to understanding the nature of the baseflow in a TMCF in the Central Mountainous region in Mexico. Based on hydrologic isotopic readings, they have proven that the baseflow can sustain the streamflow, even in a complex environment characterized by a steep topography and fractured bedrock. In the study in a TMCF site in Thailand by Hugenschmidt et al. (2014), they verified that the baseflow has presented greater predominance in relation to the overland flow. Caballero et al. (2012) studied a hydrological year in a TMCF in Central America and verified that the baseflow/streamflow ratio was approximately $80 \%$, showing a greater predominance of the baseflow in the streamflow. All these studies demonstrated that the baseflow has been predominant in TMCF sites, especially if the native forests are preserved that can improve the soil's structure and permeability and thus favor soil-water infiltration and groundwater recharge (Ma et al. 2017; Wiekenkamp et al. 2016; Pinto et al. 2015).

Mantiqueira Range region is within the Atlantic Forest biome and was also recognized by UNESCO in 1992 as one of the most important biosphere reserve on the planet mainly because of its high-water yield capacity (Bruijnzeel et al. 2010). The region is one of the most important water sources for supplying the Metropolitan region of São Paulo (Coelho et al. 2015) and for feeding hydropower reservoirs located in the Grande river basin (Pinto et al. 2015). Its importance has been highlighted as strategic to mitigate harmful effects from persistent droughts, such as the one observed in Southeastern Brazil between 2014 and 2015 (Coelho et al. 2015). Thus, to understand the water balance in 
93 TMCF catchments in Southeastern Brazil is critical for supporting management actions

94 to reduce the impacts of scarce freshwater resource.

95

Thus, the objective of this study was to reveal the intrinsic relationship between hydrology, soil, and forest in a TMCF catchment of the Mantiqueira Range, focusing on

97 the canopy rainfall interception, evapotranspiration, soil moisture, streamflow, and 98 groundwater recharge using the framework of the water balance. More specifically, we 99 sought to answer two relevant concerns that request a more comprehensive understanding 100 of the water balance: (i) is the baseflow capable of supplying water continuously over the 101 hydrological year or it is more prone to short-term fluctuations? And (ii) does the water 102 balance in the catchment in this region end up in positive (i.e., with surplus)?

103

104

2 Study site

105

\subsection{Location and forest measurements}

106

The studied TMCF is referred to as an Atlantic Forest Micro-Catchment (AFMC),

107 which is located within a larger experimental watershed called Lavrinha Creek Watershed

108 (LCW) in Mantiqueira Range, Minas Gerais State, southeastern Brazil (Figure 1). 


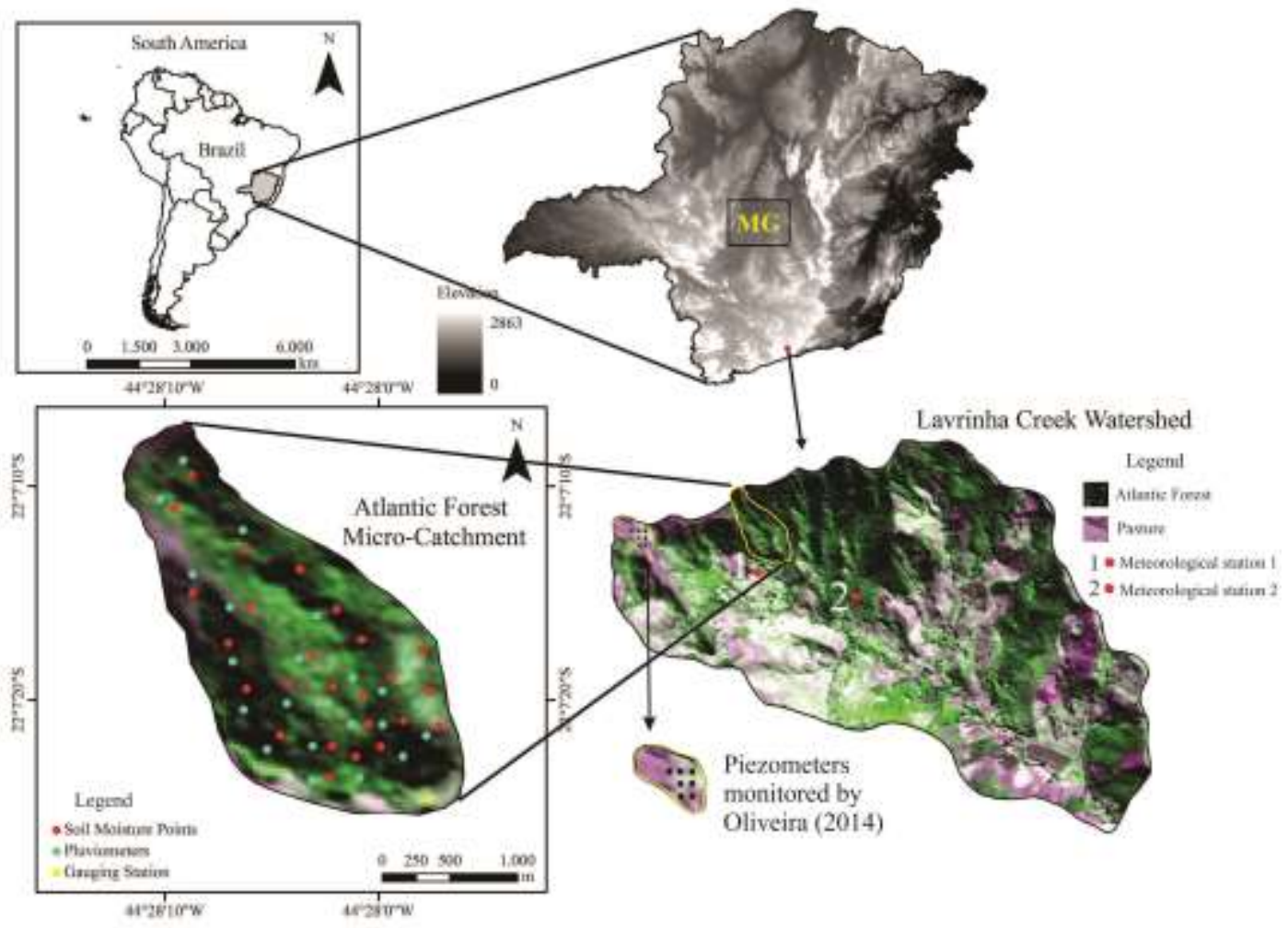

110 Figure 1. Geographical location and instrumentation used for monitoring water balance 111 elements in the AFMC, Mantiqueira Range, Minas Gerais (MG) state, southeastern Brazil.

Forest, which is a typical physiognomy of the Atlantic Forest in the Mantiqueira Range (Oliveira Filho et al. 2006). Three forest inventories (2009, 2011, and 2012) were carried out in the AFMC by Terra et al. (2015a, b). During these surveys, all trees with diameter at breast height (1.3 $\mathrm{m}$ aboveground; DBH) larger than $5 \mathrm{~cm}$ had their DBH and height measured in 12 sampling plots of $300 \mathrm{~m}^{2}$ size each randomly distributed in the AFMC. With these data, an equation adjusted by Scolforo et al. (2008), which is specific for this 
121

122

123

forest physiognomy in Mantiqueira Range region, was used for estimating the existing biomass in the AFMC. Therefore, the average density and basal area of the forest $(2185.3$ trees $\mathrm{ha}^{-1}$ and $24.5 \mathrm{~m}^{2} \mathrm{ha}^{-1}$, respectively), the average canopy height $(8.58 \mathrm{~m} \pm 1.78)$, the average Leaf Area Index (LAI) $\left(4.05 \mathrm{~m}^{2} \mathrm{~m}^{-2} \pm 1.20 \mathrm{~m}^{2} \mathrm{~m}^{-2}\right)$, and the carbon stock (39.06 $\mathrm{t} \mathrm{ha}^{-1}$ ) were calculated. The following tree species were identified by Terra et al. (2015a) as most representative in the AFMC: Lamanonia ternata Vell., Psychotria vellosiana Benth., Myrsine umbellata Mart., Myrcia splendens (Sw.) DC., Clethra scabra Pers., Guapira opposita (Vell.) Mart., Miconia sellowiana Naudin, Inga sessilis (Vell.) Mart., Alchornea triplinervia (Spreng.) Müll. Arg. and Miconia cinerascens Miq.

\subsection{Basic hydrologic and soil features at the AFMC}

Soil saturated hydraulic conductivity (Ks) at the AFMC was estimated by Pinto et al. (2015) in their study about Inceptsols hydrological role in Mantiqueira Range region. The procedure adopted was that based on the Flume datasets, sorting fourteen consecutive hourly peak discharges in the rainy season. In this procedure, Ks is estimated by applying of the Darcy's law equation. According to Pinto et al. (2015) and Libohova et al. (2018), the hydraulic gradient may be estimated by the difference elevation between the gauging station and the highest elevation of the catchment and this value is assumed being constant. This procedure can be applied if only instantaneous peak discharge values were selected during the rainy season, meaning that the soils were close to saturation. In this case, the water flows throughout the catchment as the "soil column" (Libohova et al. 2018). The derived Ks values varied from 1.3 to $23.4 \mathrm{~mm} \mathrm{~h}^{-1}$ in the AFMC. 
Overall, the saturated zone encompasses the fractured massive rock gneiss, with good permeability of saprolite (Menezes et al. 2014). These geological features 145 characterize the AFMC's capability for groundwater storage and transmittance. In general, the AFMC can be considered as a representative catchment located at elevations higher than 1,400 m within Mantiqueira Range geomorphological domain, with soils, vegetation, topography, weather, and geology being most representative of the region. Regarding the water table depth in a neighbor micro-catchment within the LCW, Oliveira (2014) monitored the water table level in 7 piezometers, and in the 2009-2011 period, it had varied from 0.8 to $1.6 \mathrm{~m}$ (Figure 2). Thus, there are indicators that the depth of the subsurface unconsolidated geology is around $1.0-1.5 \mathrm{~m}$.

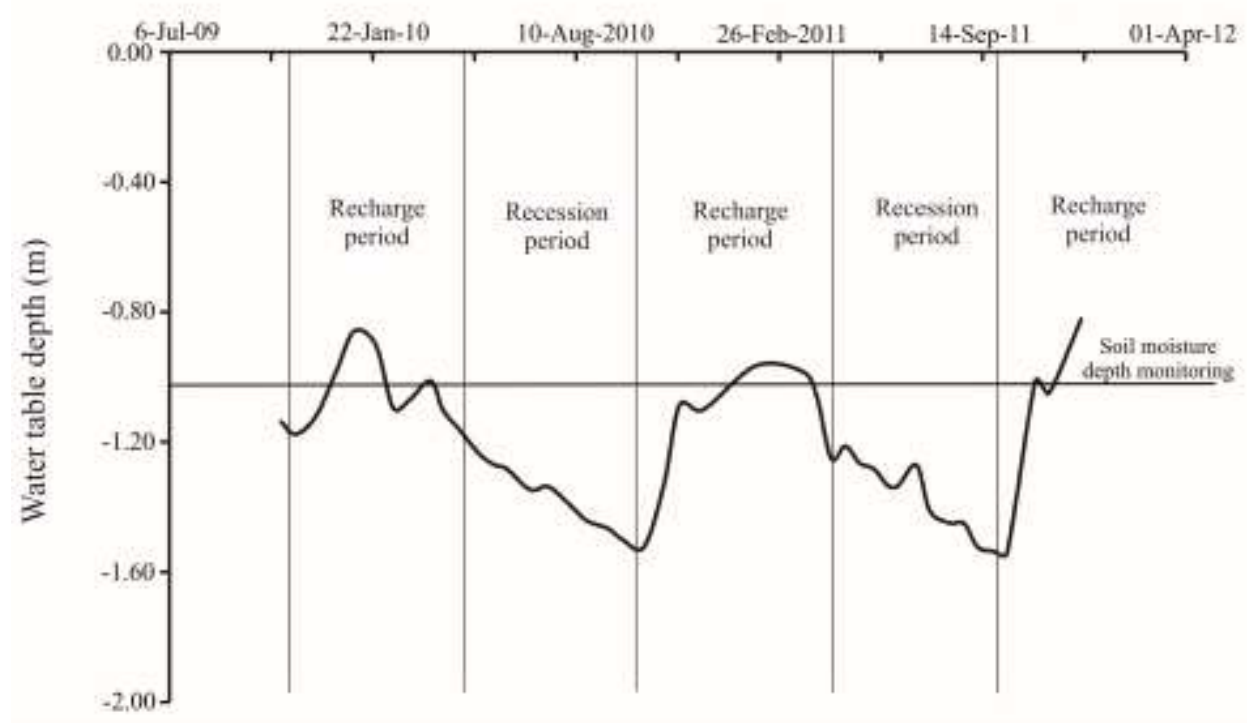

Figure 2. Average water table depth between 2009 and 2011 in an AFMC neighboring micro-catchment also located in the Lavrinha Creek Watershed as observed by Oliveira (2014) (see the piezometers' location in Fig. 1). 

$\mathrm{m}$ and $1685 \mathrm{~m}$. It has the following soil-landscape characteristics: shallow to moderately 160 deep soils (Haplic Cambisol - Inceptisols with solum varying from 0.70 to $1.20 \mathrm{~m}$ ), with 161 high concentration of organic matter in the $0-0.5 \mathrm{~m}$ layer; the parent material being granite-gneiss (Menezes et al. 2014); topography is commonly undulating, strongly undulating or mountainous, and the basin shape is narrow, with a circularity index of 1.244.

\subsection{Meteorological condition}

From 2006 to 2012, the meteorological variables (precipitation, air temperature and relative humidity, atmosphere pressure, air density, dew point, wind velocity and direction, and global solar radiation) were recorded at the LCW by two standard automatic meteorological stations separated by a distance of $740 \mathrm{~m}$ (Figure 1). The Köppen climate type for Mantiqueira Range is $\mathrm{Cwb}$, which can be summarized as temperate highland tropical climate with dry winters and rainy summers. The mean annual observed temperature between 2006 and 2012 was $16^{\circ} \mathrm{C}$ and was calculated based on the hourly values recorded by the meteorological station 2 (Figure 1). The minimum and maximum annual mean observed temperatures were $10^{\circ} \mathrm{C}$ and $23^{\circ} \mathrm{C}$ and were calculated by taking the minimum and maximum daily values from the same meteorological station. From 2006 to 2012, annual precipitation ranged from $1841 \mathrm{~mm}$ to $2756 \mathrm{~mm}$; on average, it corresponded to $2311 \mathrm{~mm}$, with $89.5 \%$ of this amount concentrated between September and March. Thus, there is a marked dry period, which 
180

181

182

183

begins in April and ends in August and the hydrological year for the studied region is defined as the period from September in one year to August in the following year.

\section{Methods}

\subsection{Components of water balance at the AFMC}

The AFMC was monitored from June 2009 to December 2011, within the scope of a wider research and development project sponsored by the Minas Gerais state Electrical Energy Company (CEMIG) and the Electrical Energy National Agency (ANEEL). This monitoring effort allowed to account the elements of water balance using two complete hydrological years. The datasets encompassed canopy rainfall interception, soil moisture, weather, streamflow, and other soil and vegetative measurements carried out during the same period.

\section{Meteorological elements and evapotranspiration}

The monitoring involved meteorological variables, which were recorded by a Campbell automatic weather station (model: "WeatherHawk" station; Station 1 - Figure 1) installed in a clear-cut area $30 \mathrm{~m}$ from the AFMC. It was assumed that these data sets are representative of the conditions at $2 \mathrm{~m}$ above the forest canopy (Fleischbein et al. 2010; Muñoz-Villers et al. 2012; Salemi et al. 2013).

Using the observed meteorological variables and the procedures used by Allen et al. (1998), the Penman-Monteith model (Monteith, 1964) was applied to estimate daily evapotranspiration $\left(\mathrm{ET}, \mathrm{mm} \mathrm{d}^{-1}\right)$ for the studied site: 


$$
\mathrm{ET}=\frac{\Delta \cdot \mathrm{Rn}+\rho \cdot \mathrm{cp} \cdot(\mathrm{es}-\mathrm{e}) \cdot \mathrm{g}_{\mathrm{a}}}{\lambda \cdot\left(\Delta+\gamma \cdot\left(1+\left(\mathrm{g}_{\mathrm{a}} / \mathrm{g}_{\mathrm{c}}\right)\right)\right)}
$$

201 where $\Delta$ is the slope of the saturation vapor pressure curve $\left(\mathrm{kPa}^{\circ} \mathrm{C}^{-1}\right) ; \lambda$ is the latent heat 202 of water vaporization $\left(\mathrm{MJ} \mathrm{kg}^{-1}\right)$; $\mathrm{Rn}$ is the net radiation $\left(\mathrm{MJ} \mathrm{m}^{-2} \mathrm{~d}^{-1}\right)$; $\rho$ is the moist air 203 density $\left(\mathrm{kg} \mathrm{m}^{-3}\right)$; $\mathrm{cp}$ is the specific heat at a constant pressure $\left(1.013 \mathrm{~kJ} \mathrm{~kg}^{-1}{ }^{\circ} \mathrm{C}^{-1}\right)$; es is the 204 saturation vapor pressure $(\mathrm{kPa})$; e is the current vapor pressure $(\mathrm{kPa})$; $\mathrm{g}_{\mathrm{a}}$ is the aerodynamic conductance $\left(\mathrm{m} \mathrm{s}^{-1}\right) ; \mathrm{g}_{\mathrm{c}}$ is the conductance of water vapor in the canopy $(\mathrm{m}$ 206 $\left.\mathrm{s}^{-1}\right)$; and $\gamma$ is the psychrometric constant $\left(\mathrm{kPa}^{\circ} \mathrm{C}^{-1}\right)$. global solar radiation, according to the following equations (Yin et al. 2008; Allen et al. 1998):

$$
\mathrm{Rn}=\mathrm{Rsw}+\mathrm{Rlw}
$$

Rsw and Rlw are short and long wave radiation $\left(\mathrm{MJ} \mathrm{m}^{-2} \mathrm{~d}^{-1}\right)$, respectively; $\mathrm{Rg}$ is the global solar radiation, which was monitored at our weather station every 60 minutes (MJ $\left.\mathrm{m}^{-2} \mathrm{~d}^{-1}\right) ; \alpha$ is the albedo, considered constant and equal to 0.12 for forests as assumed by Muñoz-Villers et al. (2012); $\mathrm{K}_{\mathrm{S}-\mathrm{B}}$ is the Stephan-Boltzman constant $\left(4.903 \times 10^{-9} \mathrm{MJ} \mathrm{K}^{-4}\right.$ $\left.217 \mathrm{~m}^{-2} \mathrm{~d}^{-1}\right) ; \mathrm{n}$ is the actual duration of sunshine (hours); $\mathrm{N}$ is the maximum duration of sunshine (hours); and $\mathrm{T}_{\text {air }}$ is the air temperature $\left({ }^{\circ} \mathrm{C}\right)$. 

observed forest data in the catchment (Allen et al. 1998). The conductance of water vapor

221 in the canopy $\left(\mathrm{g}_{\mathrm{c}}\right)$ was obtained by:

222

$$
\mathrm{g}_{\mathrm{c}}=\mathrm{g}_{\mathrm{S}} \cdot \mathrm{LAI}
$$

223

224

where $g_{s}$ is the stomatal conductance, and LAI is the leaf area index $\left(\mathrm{m}^{2} \mathrm{~m}^{-2}\right)$. The values of $g_{s}$ were estimated by Pereira et al. (2010) who studied another forested site within the LCW at similar altitudes during the dry periods of 2008 and 2009.

The LAI was monitored with a LAI2000 Plant Canopy Analyzer (Licor Biosciences, Nebraska, USA) and a sensor with a viewing angle of 180 degrees. To reduce the uncertainties of the LAI measurements, a reading with a clear sky was firstly performed as a reference. Then, 10 more readings were taken, spaced approximately 10 $\mathrm{m}$ apart within the forest in a $20 \mathrm{~m} \times 90 \mathrm{~m}$ area, following a straight path through the center of the area to avoid boundary effects, searching to cover the entire area. This procedure was repeated twice in a roundtrip path for 20 readings, always performed before 09:00 a.m. or after 3:00 p.m., and avoiding cloudy days, performed approximately twice a month.

A comparative analysis was carried out between the evapotranspiration modeled based on the equations from 1 to 5 (ET) and the evapotranspiration obtained based on the water balance method conducted during the months of the dry period (from April to August of 2010 and 2011) (ET $\mathrm{WB}_{\mathrm{BB}}$. This procedure implies that ET from the water balance was calculated mainly based on the changes in soil-water storage in the $0-1.0 \mathrm{~m}$ layer (control layer) and in observed rainfall events that normally do not have a significant 
241 impact on streamflow, mostly returning to the atmosphere by evaporation from canopy 242 (Tomasella et al. 2008). Thus, ET can be estimated by the following water balance 243 equation:

$$
\mathrm{ET}_{\mathrm{WB}}=\mathrm{TF}-\Delta \mathrm{S}_{\mathrm{USZ}}+\mathrm{C}
$$

where $\mathrm{ET}_{\mathrm{WB}}$ represents the evapotranspiration from this water balance $(\mathrm{mm}), \mathrm{TF}$ is the throughfall (mm), $\Delta \mathrm{S}_{\text {USZ }}$ is the soil-water storage change in the 0-1.0 m layer (in mm) that was taken approximately every 20 days, and $\mathrm{C}$ is the rainfall canopy interception.

Aiming to strength the validation of the ET estimated in this study, the daily estimated values were accounted for 8-day (ET 8-day), and then were compared to the values extracted from MODIS/Terra Net Evapotranspiration 8-day with 500-m of spatial resolution, considering the two studied hydrological years (ORNL DAAC, 2018; Running and $\mathrm{Mu}, 2017)$. The datasets from MODIS are also estimated based on Penman-Monteith by means of an algorithm developed by Mu et al. (2007). These datasets are validated based on ground meteorological observations and Eddy Covariance flux towers around the world (Mu et al. 2007).

\section{Rainfall canopy interception}

Twenty-five rain-gauges for throughfall measurement (model: "Ville de Paris", manufactured with a $415 \mathrm{~cm}^{2}$ orifice), were installed $1.5 \mathrm{~m}$ above the ground across the 
261

262

263

264

265

266

269

270

271

272

273

274

275

276

277

278

279

280

281

of each rainy day in an attempt to reduce problems with accumulation and overlap of rainfall events.

Rainfall events with less than $20 \mathrm{~mm}$ and separated by at least 24 hours were taken to estimate the maximum canopy storage capacity (Sc) (Cuartas et al. 2007) by means of a linear regression between the average throughfall $(\mathrm{y})$ and gross precipitation $(\mathrm{x})$. The Sc corresponds to the $\mathrm{x}$ value when $\mathrm{y}=0$. For the AFMC, Sc was equal to $1.58 \mathrm{~mm} \mathrm{~d}^{-1}$. From these readings, the canopy rainfall interception $(\mathrm{C})(\mathrm{mm})$ was determined by the following equation (Guimire et al. 2017):

$$
\mathrm{C}=\mathrm{P}-\mathrm{TF}-\mathrm{Stf}
$$

where $\mathrm{P}$ is the gross precipitation ( $\mathrm{mm}), \mathrm{TF}$ is the throughfall (averaged from 25 gauges) $(\mathrm{mm})$, and Stf is the stemflow which was not measured in this study since it is not significant from a water balance point of view (Zimmermman et al. 2013).

On computing evapotranspiration (ET) through the water balance, the interception loss (C) were added to the evapotranspiration estimated by Penman-Monteith when the canopy was not saturated $(\mathrm{C}<\mathrm{Sc})$; otherwise, when the canopy was saturated only $\mathrm{C}$ values were computed for ET, since under this condition, the transpiration can be negligible (Tomasella et al. 2008; Shuttleworth, 1992).

\section{Soil water storage (SWS)}

Twenty-five soil moisture probes (type PR2/6“ Delta-T Devices, London, UK, accuracy $0.04 \mathrm{~m}^{3} \mathrm{~m}^{-3}$ ), calibrated according to Evett et al. (2006), were installed in the 
282

283

284

285

286

287

288

289

290

291

292

293

294

295

296

297

298

299

300

301

302

same location of the rain-gauges for measuring the volumetric soil moisture in depths of $0.10 \mathrm{~m}, 0.20 \mathrm{~m}, 0.30 \mathrm{~m}, 0.40 \mathrm{~m}, 0.6 \mathrm{~m}$ and $1.0 \mathrm{~m}$. As this device does not make automatic reading of the soil moisture, we adopted a time interval between the readings of approximately 20 days. Soil water storage (SWS, in $\mathrm{mm}$ ) for each date (t) and its change between consecutive readings were calculated, respectively, by:

$$
\begin{gathered}
\mathrm{SWS}_{\mathrm{t}}=\sum_{\mathrm{i}=1}^{\mathrm{n}}\left(\frac{\theta_{\mathrm{i}}+\theta_{\mathrm{i}+1}}{2} \times \mathrm{h}\right) \\
\Delta \mathrm{S}_{\mathrm{soil}}=\mathrm{SWS}_{(\mathrm{j}+\mathrm{t})}-\mathrm{SWS}_{(\mathrm{t})}
\end{gathered}
$$

where $\theta_{\mathrm{i}}$ and $\theta_{\mathrm{i}+1}$ are, respectively, the soil moisture in the depth $\mathrm{i}$ and in the follow depth $\left(\mathrm{m}^{3} \mathrm{~m}^{-3}\right), \mathrm{n}$ is the number of layers $(0-0.10 \mathrm{~m} ; 0.1-0.2 \mathrm{~m} ; 0.20-0.30 \mathrm{~m} ; 0.30-0.40 \mathrm{~m}$; $0.40-0.60 \mathrm{~m} ; 0.60-1.0 \mathrm{~m}), \mathrm{h}$ is the layer thickness $(\mathrm{mm})$ and $\mathrm{j}$ is the time interval. In addition, we calculated the SWS for the layers of $0-0.20 \mathrm{~m}$ (surface layer), $0.20-0.60$ $\mathrm{m}$ (intermediate layer) and $0.60-1.0 \mathrm{~m}$ (deeper layer) for studying the statistical relationship with the streamflow components.

\section{Streamflow}

The streamflow in the AFMC was monitored by means of a Parshall flume and an automatic water level sensor (model WL16 Global Water Instrumentation, California, USA). The discharges were recorded at 60 -min by the datalogger of the instrument. The hydrographs analyses were based on the daily discharge value. The procedure was carried out by the separation of the baseflow from the total streamflow by identification of the inflexion point in the recession limb from the baseflow and the beginning of the overland 
303

304

305

306

307

308

309

310

311

312

313

314

315

316

317

318

319

320

321

322 flow (Hingray et al. 2014). The baseflow follows the fundamentals of the Maillet exponential equation (Dewandel et al. 2002):

$$
\begin{aligned}
& \frac{\mathrm{dQ}}{\mathrm{dt}}=-\alpha \cdot \mathrm{Q} \\
& \mathrm{Q}_{\mathrm{t}}=\mathrm{Q}_{\mathrm{O}} \cdot \exp (-\alpha \cdot \Delta \mathrm{t})
\end{aligned}
$$

$\mathrm{Q}_{0}$ is the initial flow rate $\left(\mathrm{m}^{3} \mathrm{~s}^{-1}\right), \mathrm{Q}_{\mathrm{t}}$ is the flow rate $\left(\mathrm{m}^{3} \mathrm{~s}^{-1}\right)$ at time $\mathrm{t}$ (daily), $\alpha\left(\mathrm{d}^{-1}\right)$ is the recession coefficient, and $\Delta \mathrm{t}$ the number of days between consecutive flows.

The baseflow contribution to the streamflow was assessed using the baseflow index (BFI) (Clark et al. 2014; Muñoz-Villers and McDonnell, 2013; Caballero et al. 2012) as follows:

$$
\operatorname{BFI}(\%)=\left(\frac{\text { total volume of baseflow }}{\text { total volume of streamflow }}\right) \times 100
$$

In order to assess possible connections between streamflow, overland flow, and baseflow with evapotranspiration, throughfall, and SWS at three different soil layers (0 $0.20 \mathrm{~m} ; 0.20-0.60 \mathrm{~m} ; 0.60$ to $1.0 \mathrm{~m})$, multiple regressions using the stepwise approach based on the Akaike Information Criterion (AIC) for the selection of independent variables were fitted. These analyzes have focused to demonstrate how the unsaturated zone can influence the streamflow in a TMCF like the AFMC.

\subsection{Water balance}

The daily water balance was calculated based on the following equation:

$$
\mathrm{S}_{\mathrm{AFMC}(\mathrm{i}+1)}=\mathrm{S}_{\mathrm{AFMC}(\mathrm{i})}+\mathrm{P}_{(\mathrm{i})}-\mathrm{ET}_{(\mathrm{i})}-\mathrm{SF}_{(\mathrm{i})}
$$


323 where $\mathrm{S}_{\mathrm{AFMC}}(\mathrm{i})$ is the water storage in AFMC in $\mathrm{i}^{\text {th }}$ day $(\mathrm{mm}), \mathrm{S}_{\mathrm{AFMC}(\mathrm{i}+1)}$ is the water 324 storage in AFMC in the following day $(\mathrm{mm}), \mathrm{P}_{(\mathrm{i})}, \mathrm{ET}_{(\mathrm{i})}$ and $\mathrm{SF}_{(\mathrm{i})}$ are, respectively, the 325 rainfall, evapotranspiration, and streamflow in the $\mathrm{i}_{\text {th }}$ day; all variables in $\mathrm{mm}$. time interval adopted for soil moisture measurements ( $\approx 20$ days). The following equation was applied:

$$
\mathrm{GS}_{(\mathrm{j})}=\Delta \mathrm{S}_{\mathrm{AFMC}(\mathrm{j})}-\Delta \mathrm{S}_{\text {soil }(\mathrm{j})}
$$

$\Delta \mathrm{S}_{\mathrm{AFMC}(\mathrm{j})}, \Delta \mathrm{S}_{\text {soil(j) }}$ and $\mathrm{GS}_{(\mathrm{j})}$ are, respectively, the water storage variation in AFMC accounted based on equation 13, in the soil-layer of $0-1.00 \mathrm{~m}$ (unsaturated zone), accounted based on equation 9 , and potential groundwater recharge, in the $\mathrm{j}^{\text {th }}$ period of approximately 20 days.

The $0-1.0 \mathrm{~m}$ layer was considered for $\Delta \mathrm{S}_{\text {soil }}$ measurement as the maximum observed solum depth being $1.20 \mathrm{~m}$ (Menezes et al. 2014) and the saturated zone of the catchment varied from $0.8 \mathrm{~m}$ and $1.6 \mathrm{~m}$ during the studied hydrological years (Figure 2). These assumptions allowed the estimation of potential groundwater recharge that occurred during the time interval of the soil moisture readings. 
3434 Results

$344 \quad 4.1$ Water balance elements at the AFMC between 2009 and 2011

\section{$345 \quad$ Rainfall and throughfall}

Figure 3a shows the temporal behavior of the gross precipitation (meteorological

347 station 1 - Figure 1) and the average throughfall and its respective standard errors (mm), 348 calculated based on the spatial variability of the records, between 2009 and 2011. Figure

$3493 \mathrm{~b}$ presents the mean monthly precipitation and respective standard deviation for the 350 LCW (meteorological station 2) based on the monitored period from 2006 to 2012. The 351 observed gross precipitation for the hydrological year of 2009-2010 was 2,250 mm and 352 for the 2010-2011 hydrological year, 2,756 $\mathrm{mm}$. 


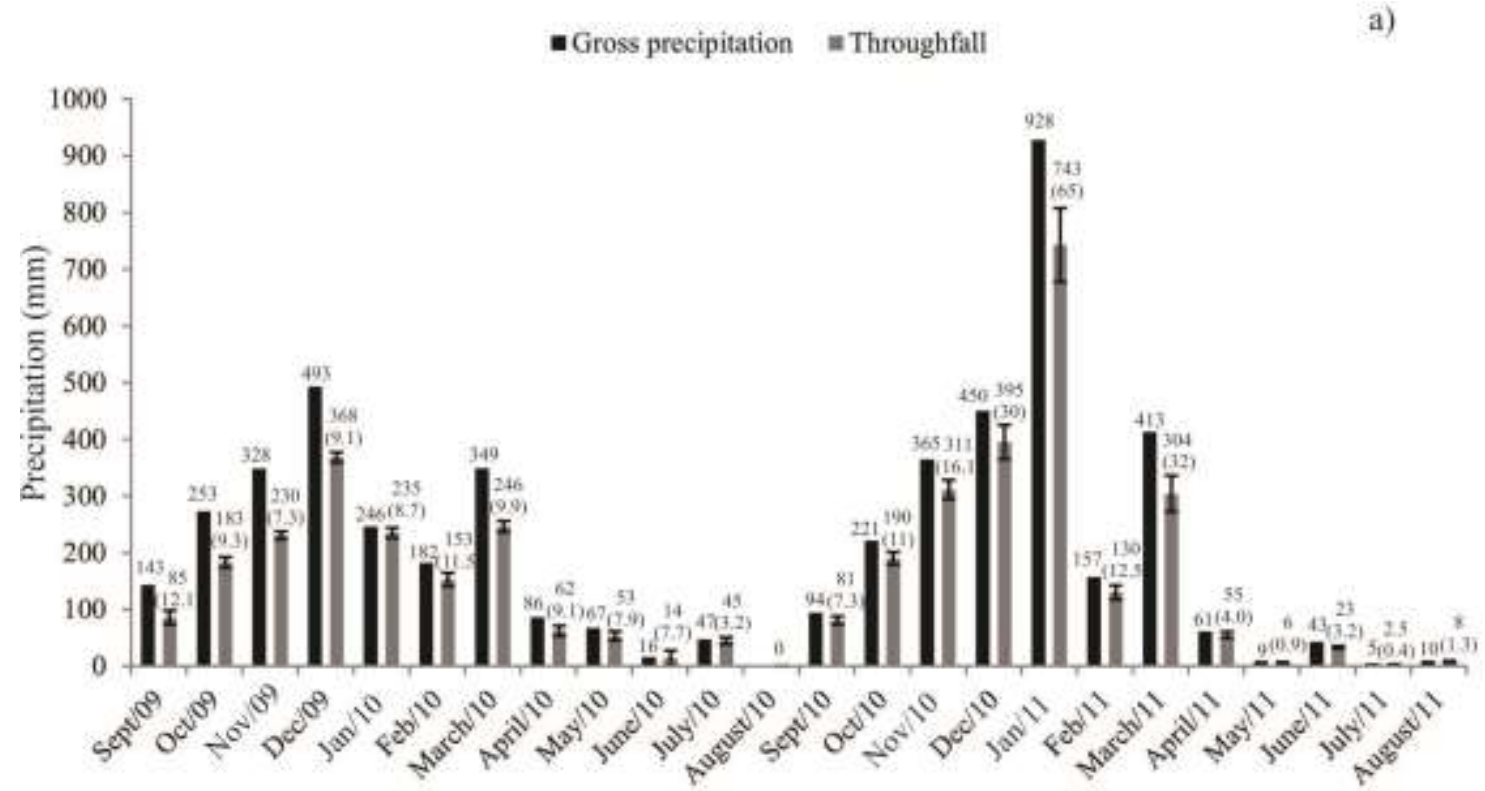

Period of Monitoring

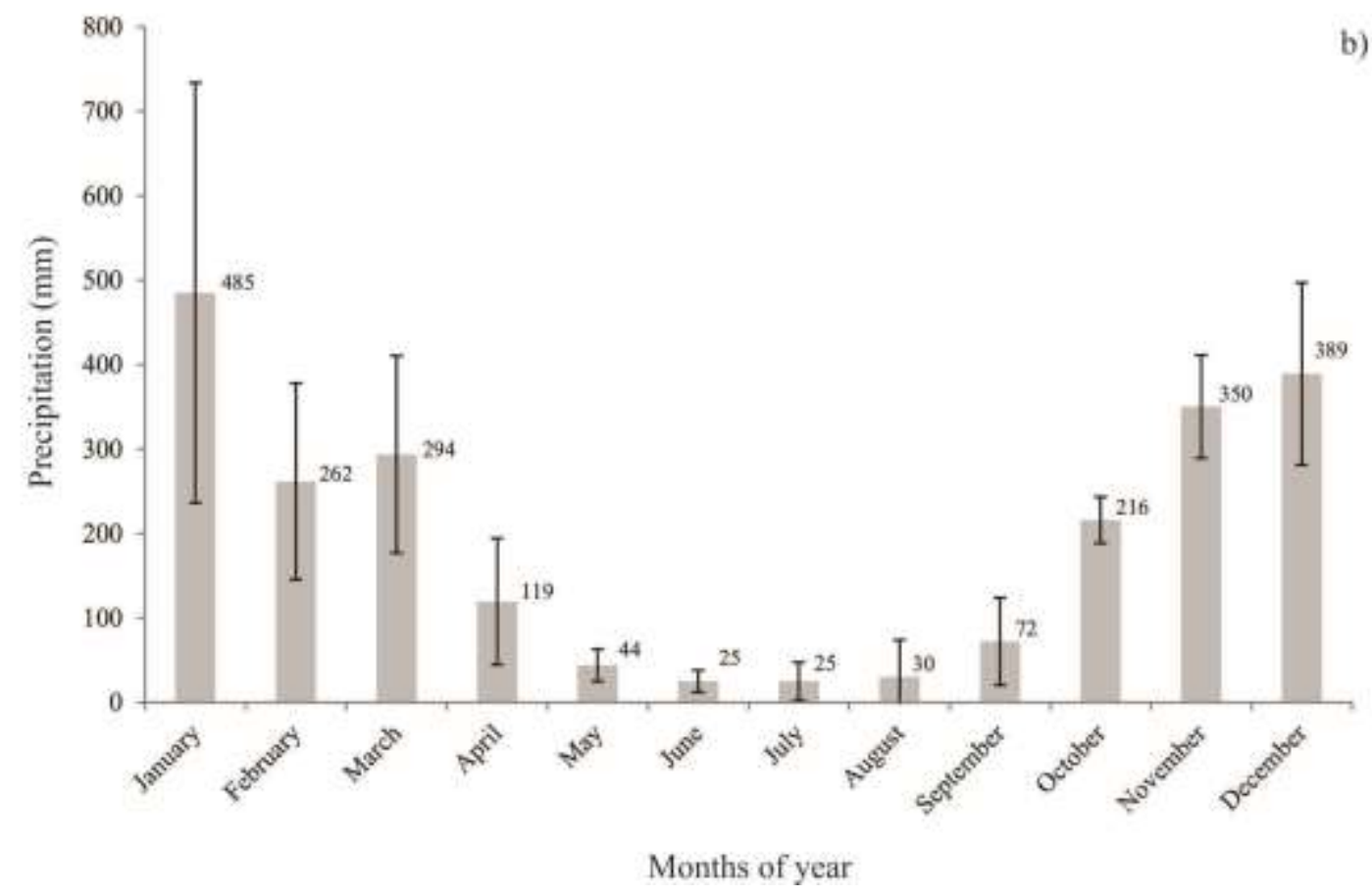

354 Figure 3. Monthly gross precipitation, throughfall and its standard errors as observed in 355 the AFMC during the hydrological years of 2009-2010 and 2010-2011 (a) and average 356 monthly gross precipitation and respective standard deviation as observed in the Lavrinha 357 Creek Watershed from 2006 to 2012 (b). 
In Table 1, it is presented the results of the studied meteorological variables split

359 into seasons of the year. It was observed for the hydrological years of 2009/2010 and $3602010 / 2011$, C/P ratio of 21.3 and 20.5\%, respectively. For the wet season of 2009-2010, 361 it was observed $20.9 \%$ of interception, whereas for $2010 / 2011$, this value was practically 362 the same, $20.8 \%$.

363 Table 1.

\section{Evapotranspiration}

Daily average values of ET modeled (ET) (equation 1) and ET from the water balance carried out during the dry periods (April - September/2010 and 2011) (ETWB)

367 (equation 6) were analyzed to produce the statistical relationship presented in Figure 4a. 368 In addition, the ET 8-day values estimated in this study were compared to the ET 8-day 369 extracted from MODIS Global Terrestrial Evapotranspiration Product (ORNL DAAC, 370 2018; Running and $\mathrm{Mu}, 2017$ ) and the results are presented in Figure 4 (b, c). Both 371 validation procedures are essential for the study since ET accounts for the greatest portion 372 of the water balance. 


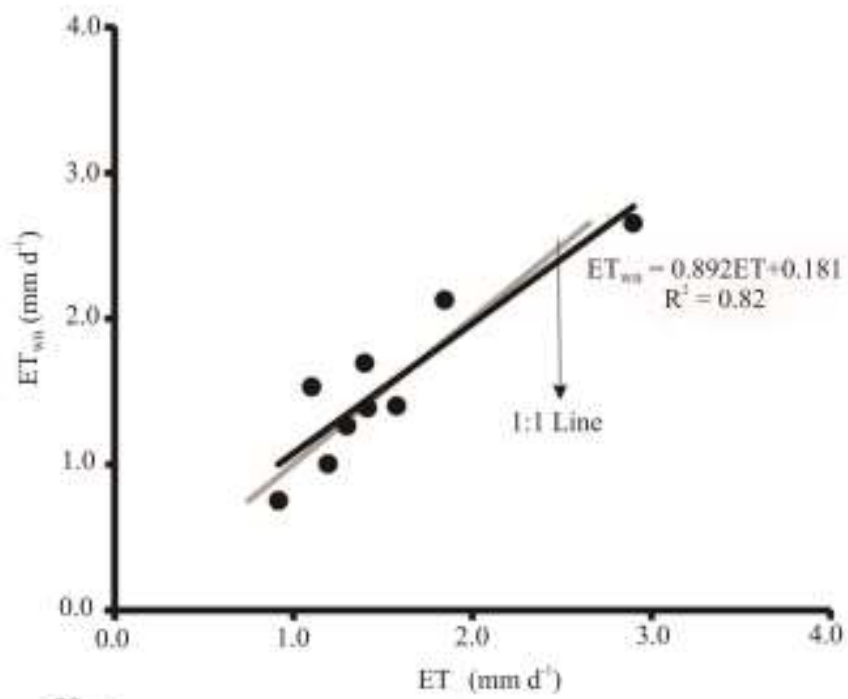

a)
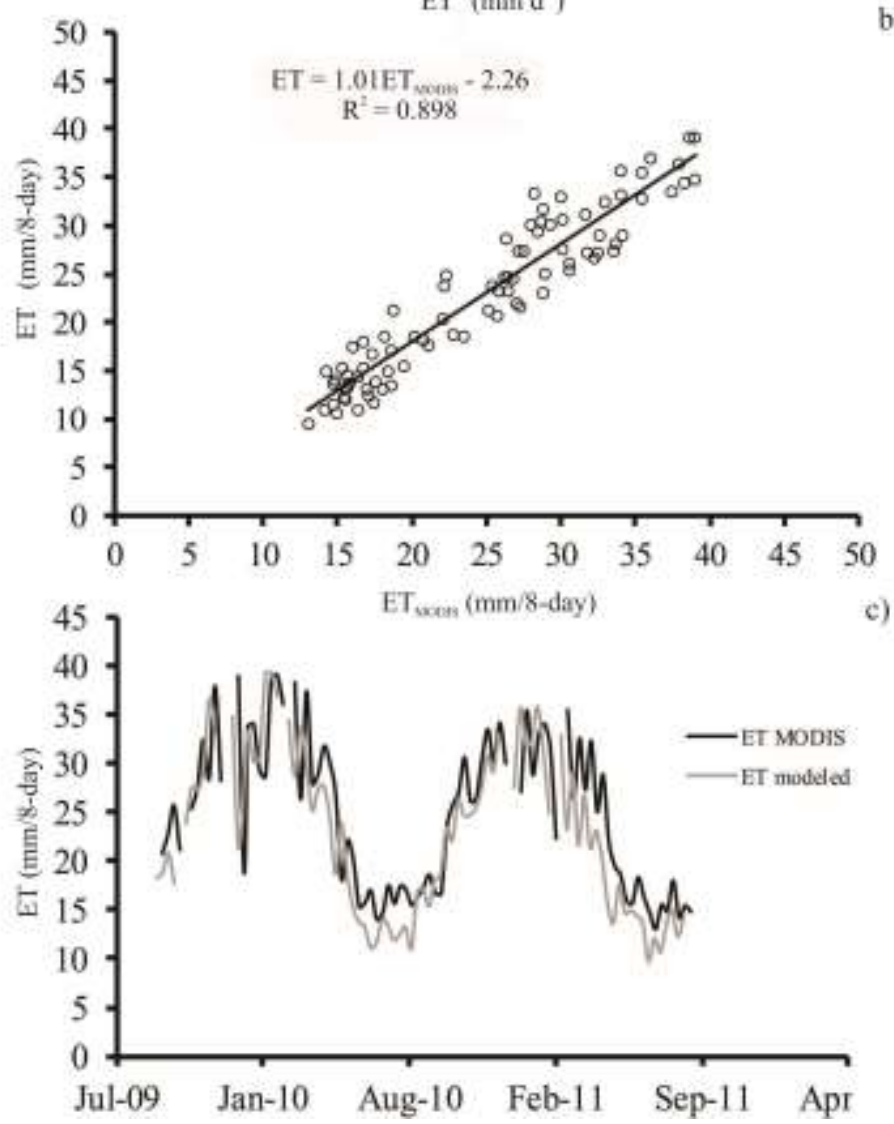

374 Figure 4. Relationship between evapotranspiration modeled (ET) and evapotranspiration

375 from water balance $\left(\mathrm{ET}_{\mathrm{WB}}\right)$ during the dry periods in AFMC site (a), and comparison 376 between ET 8-day modeled and ET 8-day from MODIS (b, c). 

hydrological years: from $1172 \mathrm{~mm}$ year $^{-1}$ (54.8\% of P) to $1208 \mathrm{~mm} \mathrm{year}^{-1}$ (45.3\% of P), respectively, for 2009/2010 and 2010/2011.

381 presented in Figure 5a, which varied from 2.8 to $5.2 \mathrm{~m}^{2} \mathrm{~m}^{-2}$. Figure 5 also shows ET (b), 382 air temperature (c), and net radiation (d) throughout the study period for the AFMC, 383 showing the correlated patterns of the meteorological variables and the ET.

Figure 5. Temporal behavior of the leaf area index (monthly) (a), evapotranspiration (daily and monthly values) (b), air temperature (hourly, daily and monthly values) (c), and net radiation (daily and monthly values) in the AFMC throughout the studied period (2009 to 2011).

\section{Soil water storage (SWS) and streamflow}

Figure 6 presents the temporal dynamics of SWS and its respective limits points in the AFMC for the layers of $0-0.20 \mathrm{~m}, 0.20-0.60 \mathrm{~m}$ and $0.60-1.0 \mathrm{~m}$. 

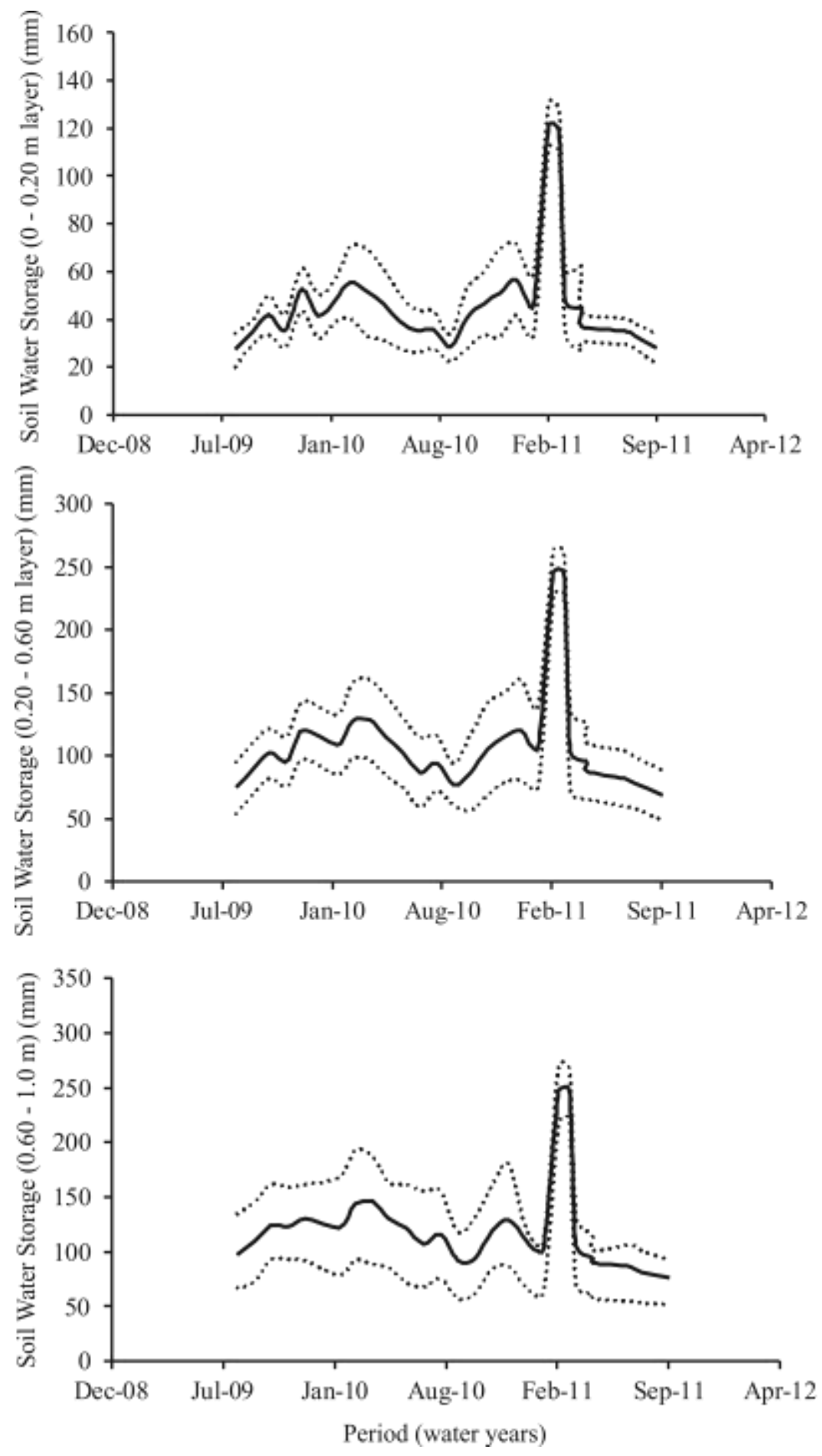

395 Figure 6. Soil Water Storage dynamics (average and upper and lower limits calculated 396 based on the 25 locations for soil moisture measurement - Figure 1) throughout the 397 hydrological years from 2009 to 2011. 
399 Figure 7 in a daily time-step. Here it is possible to observe a predominance of rainfall 400 intensity values lower than $5 \mathrm{~mm} \mathrm{~h}^{-1}$, in both hydrological years and only a few events 401 higher than $20 \mathrm{~mm} \mathrm{~h}^{-1}$. The seasonality of the rainfall is clearly transferred to the 402 streamflow, with the highest peak discharges observed in the summer.

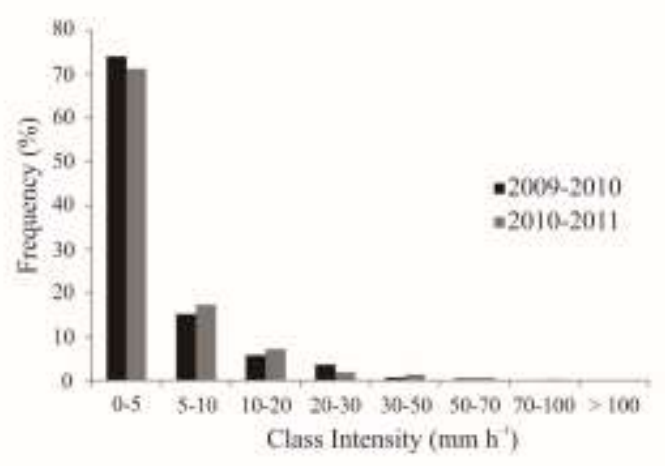

a)

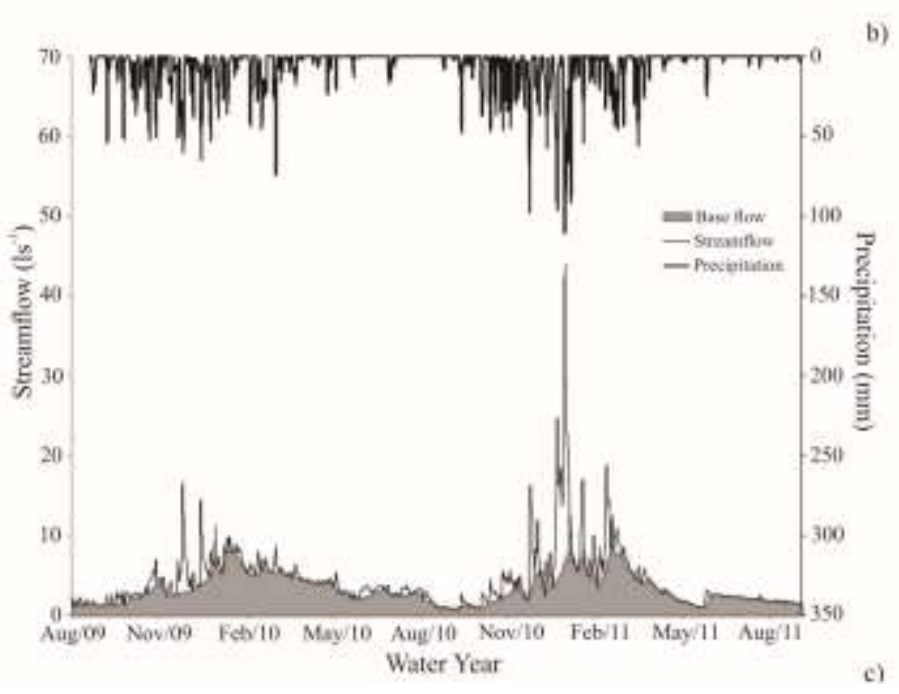

404 Figure 7. Classes of rainfall intensity frequency (a) and daily streamflow, base flow and 405 rainfall (b) throughout the hydrological years in the AFMC. 
407

408

409

410

411

412

413

414

415

416

417

418

419

420

421

422

423

424

425

426

The baseflow index (BFI) values are presented in Table 2 for both wet and dry seasons calculated for the AFMC. In this study, the BFI was 0.77 and 0.70 , respectively, for the hydrological years of 2009/2010 and 2010/2011.

\section{Table 2.}

Regarding the possible connections between baseflow and/or overland flow vs. soil water storage (SWS), evapotranspiration, and throughfall, stepwise multiple regressions were fitted and shown in Table 3.

\section{Table 3}

\subsection{Water balance}

Figure 8 shows the daily water balance at the AFMC calculated throughout the two hydrological years. Taking both Table 4 and Figure 8 , it is possible to infer about potential groundwater recharge in the catchment throughout the hydrological years. Based on the water storage in the AFMC and the changes on soil-water storage up to 1.0 $m$ in depth $\left(\Delta S_{\text {soil }}\right)$, we estimated the potential GS by application of the equation 14 . During the wet seasons (Oct-March), with the occurrence of rainfall, the positive changes in water storage can also be observed as well as increase in the AFMC's water storage (Figure 8). In 2009/2010 hydrological water, a potential recharge of $403.8 \mathrm{~mm}$ was estimated, and for 2010/2011, $710.5 \mathrm{~mm}$. In addition, a positive water storage stands out in the end of the hydrological years, with $203 \mathrm{~mm}(9.5 \%$ of P) and $554.5 \mathrm{~mm} \mathrm{(20.9 \%} \mathrm{of}$ $\mathrm{P})$, respectively. 
429 Figure 8. Daily water balance variation, potential groundwater recharge and daily rainfall

430 in the AFMC during the hydrological years of 2009/2010 and 2010/2011.

\section{$431 \quad$ Table 4.}

432

433

434

435

436

437

438

439

5 Discussion

440

5.1 Water balance elements at the AFMC between 2009 and 2011

441

\section{Rainfall and throughfall}

A seasonality behavior of the gross precipitation and throughfall could be highlighted in the AFMC, following the rainfall pattern of the region, which is

444 characterized by a wet (summer) and a dry (winter) seasons. Comparing gross 445 precipitation observed in the AFMC to the average value observed in the LCW (2311 mm $446 \pm 470 \mathrm{~mm}$ ) (Figure 3b), it can be inferred that the 2009-2010 hydrological year was closer 
447 to the expected rainfall pattern for the Mantiqueira Range region. For hydrological year of 2010/2011, it was observed a total rainfall considerably higher than the average along with a greater concentration of rainfall in the wet season $(92 \%$ of the total vs. $84 \%$ observed for 2009/2010 hydrological year). These differences can be partially attributed to an anomalous value observed in January 2011 (928 mm), which is larger than the upper boundary of the $75 \%$ inter-quartile for this month (Figure 3b). Its occurrence was attributed to a specific weather condition that predominated over southeastern Brazil, a South Atlantic Convergence Zone episode associated with higher temperatures over the Subtropical Atlantic Ocean, which contributed with greater moisture in the atmosphere, and thus more rain for the coast of the region and surroundings (Marengo and Alves, 2012).

One of the main sources of error in gross precipitation monitoring is the wind influence, which was considered negligible due to the low annual average value in both stations $\left(1.55 \mathrm{~m} \mathrm{~s}^{-1}\right)$. Another important source is the spatial variability due to microclimates formed in mountainous landscape and the rainfall events provoked by orographic effects. A comparison between these stations, which are separated by $740 \mathrm{~m}$, demonstrated a difference of $55 \mathrm{~mm}$ (2.4\% of the total) and $105 \mathrm{~mm}$ (3.8\%), respectively, for the first and second hydrological years. Thus, these values demonstrate an acceptable difference for gross precipitation over LCW.

Overall, rainfall canopy interception in relation to rainfall $(\mathrm{C} / \mathrm{P})$ varied slightly between the hydrological years, with an average value of $20.9 \%$ (Table 1). In other studies conducted in TMCF sites similar results were observed, such as Ghimire et al. (2017), in Madagascar, and Muñoz-Villers et al. (2012), in Mexico. On the other hand, Salemi et al. 
470

471

472

473

(2013) found a C/P ratio of 33\% for a TMCF site in "Serra do Mar" region, with an altitude under $1,100 \mathrm{~m}$. This difference is related to the species found in the site studied by Salemi et al. (2013), highlighting its larger leaves, a canopy more closed and species' morphology with greater biomass.

Standard errors related to throughfall are also depicted in Figure 3 a for the AFMC. According to Munõz-Viller et al. (2012), the main source of uncertainty for these records is the spatial variability below the canopy. The results found here indicate that there was low variability of these data from most rain gauges, especially for the first hydrological year. This observed spatial variability for throughfall also demonstrates that the rain gauges are reasonably spatially distributed below the canopy.

\section{Evapotranspiration}

The ET model adopted in this study was capable of adequately estimate ET for the AFMC, supported by the meteorological data, and stomatal conductance estimated based on observed leaf area index (Figure 5a). In Figure 4a, it is presented the relationship between $\mathrm{ET}$ and $\mathrm{ET}_{\mathrm{WB}}$. The hypothesis test of the unit slope and the intercept equaling to zero showed that the fitted regression line is not significantly different from the 1:1 line ( $p=0.15$ and 0.41 , respectively, for the angular and linear coefficients). This means that the modeled ET values were close to those calculated from the water balance conducted 
491

492

493

494

495

496

497

498

499

500

501

502

503

504

505

506

507

508

509

510

511

512

513

considering only the dry periods of the hydrological years, which was dominated by the changes in soil water storage.

Figure $4(b, c)$ shows the relationship between ET modeled in the study and ET extracted from MODIS satellite for 8-day values (ET 8-day), showing a satisfactory precision of the estimates (Figure 4b) along with an adherence between the two throughout the time (Figure 4c). In general, ET MODIS values were slightly greater than ET modeled by approximately $8.5 \%$.

Evapotranspiration varied slightly between the two hydrological years, which is consistent with a Dense Ombrophilous Forest, mainly due to the sites above the elevation of 1,400 m. Clark et al. (2014) estimated ET values in the TMCF in the Andes region varying from 1000 to $1300 \mathrm{~mm} \mathrm{year}^{-1}$, close to those values obtained in this study. However, upon analyzing the water balance, through an approach similar to the one of this study, in two TMCF sites in Mexico, Muñoz-Villers et al. (2011) estimated ET values of approximately $790 \mathrm{~mm}$ for both their catchments.

For a TMCF site located in Serra do Mar, Salemi et al. (2013) found a ET/P relation of $56 \%$ during a hydrological year; however, the authors did not monitor the soil moisture, considering the variation of water storage in the catchment equal to zero in the end of the hydrological year. The ET/P ratio in the AFMC was lesser in the 2010-2011 year, similar to that value found by Zema et al. (2018), who modeled the water balance in a watershed located between 1,100 and 1,200 m using the AnnAGNPS model, obtained a ET/P ratio of $45 \%$. In the case of the AFMC, this can be justified by the large number of rainy days in the period between November and March, which was associated with a saturation of the canopy and a reduction on impact of transpiration during this period. A 
514 detailed analysis of the precipitation records revealed that there were $2,463 \mathrm{~mm}$ of rainfall 515 during the aforementioned period. Out of the 151 days of the period, $92(60.9 \%)$ were 516 found to be rainy compared to only 67 (44.4\%) for the same period in the 2009-2010 year.

517 Therefore, we can state that there was a greater surplus water in the catchment available 518 to sustain the streamflow in this hydrological year.

It is important to highlight that all the meteorological variables present a marked seasonality which is the most significant climatic feature of the region with implications for the water balance. When evaluating ET throughout the time, it is possible see that it follows the LAI, net radiation, and temperature oscillations (Figure 5), demonstrating the importance of these meteorological variables to explain the water demand by the forest.

524 In wet season, LAI values have oscillated around $5 \mathrm{~m}^{2} \mathrm{~m}^{-2}$, and the daily 525 evapotranspiration (transpiration + wet-canopy evaporation) close to $4 \mathrm{~mm} \mathrm{~d}^{-1}$. In the winter, LAI values oscillated around $3 \mathrm{~m}^{2} \mathrm{~m}^{-2}$ while ET, $1 \mathrm{~mm} \mathrm{~d}^{-1}$. These oscillations are expected for tropical and subtropical deciduous forests and occurs due to reduction in the tree physiological activities in drier and cooler periods.

Both ET and P tended to increase over the summer, indicating atmospheric conditions more favorable to both transpiration and evaporation of the rainfall intercepted by the canopy. It is important to stress that, according to Shuttleworth (1992), the 532 participation of transpiration is greater under the conditions of a dry or moist canopy; otherwise, with a saturated canopy, evaporation is predominant. In environments like the 534 AFMC, there is a predominance of colder and rainy weather due to its elevation (greater than $1400 \mathrm{~m}$ ) and proximity to the Atlantic Ocean coast. Thus, in summer (wet period), 
536 the canopy moisture is close to saturation and it helps to sustain the greatest part of the 537 atmospheric demand.

Soil water storage (SWS) and streamflow

Soil water storage (SWS) seasonality in the AFMC is noticeable throughout the monitoring period. In general, increasing SWS from the surface to the deeper layers and greater dynamics in the $0-0.20 \mathrm{~m}$ layer can be observed. Also, the deeper the layer the higher the SWS variability, which is also related to the greater influence of the forest root system in depth (mainly in the dry season). Between February/March 2011, a strong increase in SWS affected the AFMC, impacting the overland flow in the second hydrological year, which was not observed with the same magnitude in the wet season of 2009-2010.

Pinto et al. (2015) studied the role of the Inceptsols, the dominant soil type in the study area, on the LCW's hydrology based on micromorphology images and concluded that both macro-porosity and interconnections between larger pores especially at the 0$0.20 \mathrm{~m}$ layer are fundamental for infiltration capacity of these soils. It was observed that there is a clear influence of the forest on soil porosity in this surface soil layer, while in deeper soil layers there is greater micro-porosity (Pinto et al. 2015), which leads to a greater redistribution of moisture, and thus higher variability in subsoil moisture (Figure $6 a, b, c)$.

Further analyzing the daily rainfall distribution and the respective streamflow in the AFMC (Figure 7), the majority of the rainfall events has low intensity (more than $90 \%$ 
558 rainfall events were lower than $10 \mathrm{~mm} \mathrm{~h}^{-1}$ ). The greater intensity events were observed 559 for 2010-2011 hydrological year. In addition, a few rainfall events with intensity greater 560 than $50 \mathrm{~mm} \mathrm{~h}^{-1}$ were observed. The behavior of these rainfall events is similar to those 561 found by Salemi et al. (2013) and have low capacity to generate overland flow, especially 562 in a catchment entirely covered by a dense forest canopy. Examination of the SWS 563 (Figure 6) reveals extremely high values between January and March 2011, as a result of 564 more than $900 \mathrm{~mm}$ of rain.

The BFI behavior in the AFMC was similar to those observed at other TMCF sites, with baseflow having a significant participation in the streamflow, which is particularly evident during the dry season. In these seasons, this coefficient was 0.84 and 0.89 , respectively, for 2010 and 2011. Clark et al. (2014), in analyzing a hydrological year for

569 a TMCF in the Andes with bedrock/fractured bedrock as geological backgrounds, 570 observed BFI oscillating from 0.60 in the wet season to 0.83 in the dry season. They 571 concluded that the baseflow has been the main factor responsible for streamflow 572 maintenance. Caballero et al. (2012), in studying a TMCF in Costa Rica, also found 573 results similar to those of this study, with a BFI around 0.80 . They concluded that the 574 participation of the baseflow was significant because of the amount of groundwater stored 575 throughout the rainy season. Thus, we have demonstrated that the BFI values in the 576 AFMC are quite consistent with other studies carried out in TMCF sites around the world, 577 including Hugenschmit et al. (2014), Clark et al. (2014), Caballero et al. (2012), and 578 Crespo et al. (2011) for northern Thailand, eastern Andes (southern Peru), Costa Rica 579 (Central-America), and Equatorial Andes, respectively. 
581 significant according to the $t$-test. Stepwise regression demonstrated that the overland

582 flow could be well explained by the throughfall and SWS at $0.20-0.60 \mathrm{~m}$ layer.

583 However, for the baseflow only SWS at 0.60-1.0 m layer was significant and positively

584 correlated. The positive correlation between overland flow and SWS at $0.20-0.60 \mathrm{~m}$ can

585 be explained based on the fact that throughfall infiltrates rapidly through $0-0.20 \mathrm{~m}$ layer

586 via macro-pores (Pinto et al. 2015), whose breakthrough leads to a saturation in the sub-

587 surface layer $(0.20-0.60 \mathrm{~m})$ that leads to overland flow. The SWS at the deepest layer

$588(0.60-1.0 \mathrm{~m})$ presented a significant but negative correlation with overland flow;

589 whereas for baseflow, it was significant but positive, suggesting that this layer is well 590 connected to the baseflow. In this sense, we can infer that SWS at the $0.60-1.0 \mathrm{~m}$ layer 591 played an important role in the saturated zone water storage capability in the AFMC.

\subsection{Water Balance}

595

A marked predominance of positive water storage in the catchment in the wet seasons (2009/2010 and 2010/2011) stands out. Larger values for wet season of 2010/2011 can be observed as a result of the significant amount of rainfall observed in the region in this period. Additionally, we can also see that the AFMC is very sensitivity to the rainfall occurrence, being the water balance elements on wet season more dynamic, showing a quick respond even for slight rainfall occurrence. 
The results presented in Table 4 allow us to demonstrate that water storage in the 602 AFMC has an important role for the baseflow. The capability of the AFMC for water 603 storage during the wet season, and how the catchment deals with it throughout the 604 hydrological years are fundamental for maintenance of the streamflow in the recession 605 period. Muñoz-Villers et al. (2016) studied the baseflow behavior on the basis of water

606

607 transit time, by means isotope hydrology in a TMCF in Mexico. They found that the resident time in the saturated zone of the catchment varied from 1.2 to 2.7 years, concluding on the possible controls of baseflow by long subsurface flow paths that are related to the permeability of soil-bedrock interface. Clark et al. (2014) and Caballero et al. (2012), both carrying out studies in TMCF sites in Andes and Central America, respectively, observed a significant participation of the baseflow, which indicates that it sustains the streamflow throughout the dry period. Clark et al. (2014) further discussed aspects regarding the hydrogeology of the catchment, showing a considerable amount of groundwater along with possible existence of fractures in the bedrock.

Muñoz-Villers et al. (2016) characterized a TMCF site in Mexico with a soilbedrock interface along with saturated hydraulic conductivity (Ks) varying from 1 to 15 $\mathrm{mm} \mathrm{h}^{-1}$ for $65 \%$ of the catchment's area. Based on these Ks values, they characterized the transition between the saprolite and bedrock as of high permeability, favoring the groundwater storage and movement in the catchment. A similar relation may be established for the studied AFMC as Ks values ranged from 1.4 to $23.7 \mathrm{~mm} \mathrm{~h}^{-1}$, and fractured bedrock, colluvial deposits, and permeable saprolite are the main geological features for Mantiqueira Range region (Pinto et al. 2015). Thus, there are indications that the baseflow in the AFMC is sustained by hydrogeological functions described as of good 
624 permeability in the transition between saprolite and bedrock, not linked to short-term 625 fluctuations.

626

627

628

630

631

632

633

634

635

636

637

638

639

640

641

642

643

644

645

In addition, the AFMC has a narrow shape (the circularity index is 1.244), and under this condition, the hydrological connectivity between hillslopes and the drainage systems is higher than for rounded catchment shapes, which increase the frequency of water table formation (Hrachowitz et al. 2009).

Differences in the water balance elements between the two hydrological years could be noticed. The greater amount of GS estimates is linked to: (i) the total precipitation in 2010/2011 is much greater than what was observed for 2009/2010, besides more concentrated. In January/2011, it was observed more than $900 \mathrm{~mm}$ and a greater number of rainy days, affecting the water balance components in a different manner as compared to 2009/2010; (ii) these impacts could be observed on the greater streamflow, lower canopy interception and ET, saturation of the soil profile and thus, a larger amount of water surplus available for storage in the AFMC. Therefore, we could observe a more significant GS for the AFMC, which was reflected in a greater baseflow participation in the dry season of 2011, given by the greatest BFI observed during the studied period (0.89 - Table 2).

Some limitations need to be highlighted in this study. First of all, we did not evaluate the impact of condensation on the water balance, as done by Clark et al. (2014), who demonstrated that almost $10 \%$ of the baseflow is formed by this source of water. Furthermore, similar to Clark et al. (2014), Muñoz-Villers et al. (2012), Caballero et al. (2012) and Salami et al. (2013), deep percolation into the groundwater system was not detailed in a daily time-step and we calculated a potential recharge based on the readings 
647 of soil moisture for each 20 days (equation 15). However, the existence of a great water 648 storage capacity in the AFMC was demonstrated based on the daily water balance, which 649 was the first study with this time resolution encompassing two complete hydrological 650 years in this kind catchment in Brazil.

Despite the above limitations, our TMCF site is within a Biosphere Reserve

652

653

654

655

656

657

658

659

660

661

662

663

664

665

666

667

668

recognized as one of the most important ones on the planet, mainly due to its hydrologic behavior. The datasets involved in this study bring important insights into the water balance and streamflow connections. Our findings show some important novelties: (i) the baseflow is the primary source for streamflow and it was not linked to short-term fluctuations of rainfall; (ii) we could demonstrate that the catchment can store water in the wet season aiming to maintain the permanent streamflow even in the recession phase of the hydrological year; (iii) these results can be applied to support ecological services in mountainous catchments in southeastern Brazil, giving the necessary scientific support for protection of the Atlantic Forest biome, showing its relevance in reducing harm effects from droughts that have threatened this Brazilian region in recent years.

\section{Conclusions}

This study is among the first efforts to understand the water budget in a mountainous forest located above $1400 \mathrm{~m}$ asl in Brazil. Baseflow is found to be the main hydrological element in this catchment that maintains the streamflow, not only during the recession phase, but also for longer periods especially during prolonged droughts. The baseflow is attributed to groundwater storage capacity that has helped sustain the streamflow. Major findings of this study are summarized as follows: 
669

670

671

672

673

674

675

676

677

678

679

680

681

682

683

684

685

686

687

688

689

a) Rainfall interception by canopy (C) was significant and corresponded to $21.3 \%$ and $20.5 \%$ of the gross precipitation (P) in wet seasons of 2009/2010 and 2010/2011 hydrological years, respectively, with an average of $20.9 \%$ throughout the hydrological years; while evapotranspiration corresponded to an average of $50 \%$ of $\mathrm{P}$, with a greater demand in the wet season of 2010/2011 due to both greater interception and the atmospheric demand;

b) Streamflow accounted for $34.8 \%$ of $\mathrm{P}$, with high predominance of baseflow, being $77 \%$ and $70 \%$, respectively, for 2009/2010 and 2010/2011 hydrological years; noteworthy was a slightly greater predominance of overland flow in the second hydrological year as compared to the first hydrological year due to greater amount and more intense rainfall events;

c) Both hydrological years closed with a positive water storage in the Atlantic Forest Micro-Catchment, corresponding to $9.5 \%$ and $20.9 \%$ of $\mathrm{P}$ for $2009 / 2010$ and 2010/2011, respectively, with an average of $15.2 \%$;

d) The predominance of water storage in the Atlantic Forest Micro-Catchment over the two hydrological years was demonstrated by means of a daily water balance, showing the resilience of this environment in terms of water yield and baseflow maintenance during dry seasons. Based on this result, the baseflow is predominant and indeed is controlled by a complex hydrogeological system, highlighting the permeability of the soil-bedrock interface that allows a significant groundwater storage in this ecosystem. 
691 The authors thank CEMIG/ANEEL (R\&D 176 Project), FAPEMIG (PPM X - 415/16) 692 and $\mathrm{CNPq}(301556 / 2017-2)$ for sponsoring this project. We also appreciate the comments 693 provided by Catena Editorial Team and anonymous reviewers that have helped improve 694 the quality of this paper.

695

696

697

698

699

700

701

702

703

References

704

Allen, R.G., Pereira, L.S., Raes, D and Smith, M. 1998. Crop evapotranspiration 705 guidelines for computing crop water requirements. Roma: FAO Irrigation and Drainage,

706 56.

707

708

Bruijnzeel, L.A., Mulligan, M., Scatena, F.N. 2011. Hydrometeorology of tropical 709 montane cloud forests: emerging patterns. Hydrological Processes, 25, 465-498. 
711 Bruijnzeel, L.A., Kappelle, M., Mulligan, M., Scatena, F.N. 2010. Tropical montane

712 cloud forests: state of knowledge and sustainability perspectives in a changing world.

713 691-740p. In: Bruijnzeel, L.A., Scatena F.N., Hamilton, L.S. (eds.). Tropical Montane

714 Cloud Forests. Science for Conservation and Management. Cambridge, Cambridge 715 University Press.

716

717 Caballero, L.A., Rimmer, A., Easton, Z.M., Steenhuis, T.S., 2012. Rainfall runoff 718 relationships for a cloud forest watershed in Central America: implications for water 719 resource engineering. Journal of the American Water Resources Association, 48 (5), $720 \quad 1022-1031$.

721

722 Clark, K.E., Torres, M.A., West, A.J., Hilton, R.G., New, M., Horwath, A.B., Fisher, J.B., 723 Rapp, J.M., Robles Caceres, A., Malhi, Y. 2014. The hydrological regime of a forested 724 tropical Andean catchment. Hydrology and Earth System Science, 18, 5377-5397. (DOI: 725 10.5194/hess-18-5377-2014).

726 Coelho, C.A.S., Cardoso, D.H.F., Firpo, M.A.F. 2015. Precipitation diagnostics of an 727 exceptionally dry event in São Paulo, Brazil. Theoretical and Applied Climatology. DOI 728 $10.1007 / \mathrm{s} 00704-015-1540-9$.

729

Crespo, P., Bücker, A., Feyen, J., Vaché, K.B., Frede, H.G., Breuer, L., 2011. Preliminary evaluation of the runoff processes in a remote montane cloud forest basin using mixing model analysis and mean transit time. Hydrological Processes, 26, 3896-3910. 
734 Cuartas, L.A., Tomasella J., Nobre, A.D., Hodnett, M.G., Waterloo, M.J., Múnera, J.C., 735 2007. Interception water-partitioning dynamics for a pristine rainforest in Central 736 Amazonia: Marked differences between normal and dry years. Agricultural, Forest and 737 Meteorology, 145, 69-83.

739 Dewandel, B., Lachassagne, P., Bakalowicz, M., Weng, P.H., Al-Malki, A., 2002. 740 Evaluation of aquifer thickness by analyzing recession hydrographs. Application to the 741 Oman ophiolite had-rock aquifer. Journal of Hydrology, 274, 248-269.

742

743 Evett, S. R., Tolk, J. A., Howell, T. A., 2006. Soil profile water content determination: 744 axil response, calibration, temperature dependence, and precision. Vadose Zone Journal, 745 $5,894-907$.

746

747 Fleischbein, K., Wilcke, W., Goller, R., Valarezo, C., Zech, W., Knoblich, K. 2010. Measured and modeled rainfall interception in a lower montane forest, Ecuador. In: L.A. Bruijnzeel, M. Kappelle, M. Mulligan, and F.N. Scatena, eds., Tropical Montane Cloud Forests. Science for Conservation and Management. Cambridge, UK: Cambridge University Press, 309-316.

752

Fleischbein, K., Wilcke, W., Valarezo, C., Zech, W., Knoblich, K. 2006. Water budgets of three small catchments under montane forest in Ecuador: experimental and modeling approach. Hydrological Processes, 20, 2491-2507. DOI: 10.1002/hyp.6212. 
757 Fleischbein, K., Wilcke, W., Goller, R., Boy, J., Valarezo, C., Zech, W., Knoblich, K. 758 2005. Rainfall interception in a lower montane forest in Ecuador: effects of canopy 759 properties. Hydrological Processes, 19, 1355-1371. DOI: 10.1002/hyp.5562

Galindo-Leal, C., Câmara, I.G. 2003. Atlantic forest hotspot status: an overview. In: C.

Ghimire, C.P., Bruijnzeel, L.A., Lubczynski, M.W., Ravelona, M., Zwartendijk, B.W., 766 van Meerveld, H.J. 2017. Measurement and modeling of rainfall interception by two differently aged secondary forests in upland eastern Madagascar. Journal of Hydrology 545: 212-225. doi: 10.1016/j.jhydrol.2016.10.032.

769

770

Hingray, B., Picouet, C., Musy, A. 2014. Hydrology: a science for engineers. Boca Raton, USA: CRC Press.

Hrachowitz, M., Soulsby, C., Tetzlaff, D., Dawson, J.J.C., Dunn, S.M., and Malcolm, I.A. 2009. Using long-term data sets to understand transit times in contrasting headwater catchments. Journal of Hydrology, 367, 237 - 248.

777 Hugenschmidt, C., Ingwersen, J., Sangchan, W., Sukvanachaikul, Y., Duffner, A., 778 Uhlenbrook, S., Streck, T. 2014. A three-component hydrograph separation based on 
779

780

781

782

783

784

785

786

787

788

789

790

791

792

793

794

795

796

797

798

799

geochemical tracers in a tropical mountainous headwater catchment in northern Thailand.

Hydrol. Earth Syst. Sci., 18, 525-537.

Jafari SM, Zarre S, Alavipanah SK, Ghahremaninejad F. 2015. Functional turnover from lowland to montane forests: evidence from the Hyrcanian forest in northern Iran. iForest doi: 10.3832/ifor1002-008.

Libohova, Z., Schoeneberger, P., Bowling, L. C., Owens, P.R., Wysocki, D., Wills, S., Williams, C.O., Seybold, C. 2018. Soil Systems for Upscaling Saturated Hydraulic Conductivity for Hydrological Modeling in the Critical Zone. Vadose Zone Journal, 17: 170051. Doi: 10.2136/vzj2017.03.0051.

Ma, Y., Li, X., L, Guo, L., Lin, H.S. 2017. Hydropedology: Interactions between Pedologic and Hydrologic Processes across Spatiotemporal Scales. Earth-Science Reviews 171:181-195.

Marengo, J. A., Alves, L.M. 2012. The 2011 intense rainfall and floods in Rio de Janeiro. Bulletin of the American Meteorological Society 93: S176.

Menezes, M.D., Silva, S.H.G., Mello, C.R., Owens, P.R., Curi, N. 2014. Solum depth spatial prediction comparing conventional with knowledge-based digital soil mapping approaches. Scientia Agricola, 71, 316-323. DOI: 10.1590/0103-9016-2013-0416. 
800

801

802

803

804

805

806

807

808

809

810

811

812

813

814

815

816

817

818

819

820

821

822

Monteith, J.I. 1964. Evaporation and environment, The State and Movement of Water in Living Organisms. Proc. 19th Symp. Soc. Exp. Biol., Swansea, Academic Press, New York (1964), pp. 205-234.

Mu, Q., Heinsch, F. A., Zhao, M., and Running, S. W. 2007. Development of a global evapotranspiration algorithm based on MODIS and global meteorology data. Remote Sensing of Environment, 111(4), 519-536.

Muñoz-Villers, L.E., Geissert, D. R., Holwerda, F., McDonnell, J. J. 2016. Factors influencing stream baseflow transit times in tropical montane watersheds. Hydrology and Earth System Science, 20, 1621-1635.

Muñoz-Villers, L.E. and McDonell, J.J. 2013. Land use change effects on runoff generation in a humid tropical montane cloud forest region. Hydrology and Earth System Science, 17, 3543-3560.

Muñoz-Villers, L.E., Holwerda, F., Gómez-Cárdenas, M., Equihua, M., Asbjornsen, H., Bruijnzeel, L.A., Marin-Castro, B.E., Tobón, C. 2012. Water balances of old-growth and regenerating montane cloud forests in central Veracruz, Mexico. Journal of Hydrology, 462-463, 53-66 (DOI: 10.1016/j.jhydrol.2011.01.062).

Muñoz-Villers, L.E., Holwerda, F., Gómez-Cárdenas, M., Equihua, M., Asbjornsen, H., Bruijnzeel, L.A., Marin-Castro, B.E., Tobón, C. 2011. Water balances of old-growth and 
823

824

825

826

827

828

829

830

831

832

833

834

835

836

837

838

839

840

841

842

843

844

845

regenerating montane cloud forests in central Veracruz, Mexico. Journal of Hydrology, 462-463, 53-66 (DOI: 10.1016/j.jhydrol.2011.01.062).

Oliveira, A.S., 2014. Recarga subterrânea de nascentes em ambientes distintos da região Alto Rio Grande, Universidade Federal de Lavras, Lavras, Brazil (Ph.D. Dissertation).

Oliveira Filho, A.T., Scolforo, J.R.S., Oliveira, A.D., Carvalho, L.M.T. 2006. Definição e delimitação de domínios e subdomínios das paisagens naturais do estado de Minas Gerais. In: J.R.S Scolforo, LMT Carvalho, eds, Mapeamento e Inventário da Flora e dos Reflorestamentos de Minas Gerais. Lavras, MG: UFLA, 21-35.

ORNL DAAC. 2018. MODIS and VIIRS Land Products Global Sub-setting and Visualization Tool. ORNL DAAC, Oak Ridge, Tennessee, USA. Accessed July 04, 2018. Subset obtained for MOD16A2 product at 22.1S,44.45W, time period: 2001-01-01 to 2018-06-10, and subset size: 6.5 x $6.5 \mathrm{~km}$. https://doi.org/10.3334/ORNLDAAC/1379.

Pereira, D.R., Mello, C.R., Silva, A.M., Yanagi, S.N.M. 2010. Evapotranspiration and estimation of aerodynamic and stomatal conductance in a fragment of Atlantic Forest in Mantiqueira Range Region, MG. Cerne, 16, 32-40.

Pinto, L.C., Mello, C.R., Owens, P.R., Norton, L.D., Curi, N. 2015. Role of Inceptisols in the Hydrology of Mountainous Catchments in Southeastern Brazil. Journal of Hydrologic Engineering. DOI: 10.1061/(ASCE)HE.1943-5584.0001275. 
847 Running, S., Mu, Q. 2017. MOD16A2 MODIS/Terra Net Evapotranspiration 8-Day L4

848 Global 500m SIN Grid V006. NASA EOSDIS Land Processes DAAC. 849 https://doi.org/10.5067/MODIS/MOD16A2.006

850

851 Salemi, L.F., Groppo, J.D., Trevisan, R., Moraes, J.M., Ferraz, S.F.B., Villani, J.P., 852 Duarte-Neto, P.J., Martinelli, L.A. 2013. Land-use change in the Atlantic rainforest 853 region: consequences for the hydrology of small catchments. Journal of Hydrology, 499, $854 \quad 100-109$.

855

856 Scolforo, J.R.S., Rufini, A.L., Mello, J.M., Oliveira, A.D., Silva, C.P.C. 2008. Equações 857 para quantidade de carbono das fisionomias, em Minas Gerais. In: Scolforo, J.R.S., 858 Oliveira, A.D., Acerbi Júnior, F.W. (eds). Inventário Florestal de Minas Gerais: Equações 859 de Volume, Peso de Matéria Seca e Carbono para diferentes Fitofisionomias da Flora 860 Nativa. Lavras, MG: Editora Ufla, 197-215.

861 Shuttleworth, W.J., 1992. Evaporation. In: D.R. Maidment, (ed.) Handbook of 862 Hydrology, chap.4, 53p.

863

864 Tabarelli M, Aguiar AV, Ribeiro MC, Metzger JP, Peres CA (2010) Prospects for 865 biodiversity conservation in the Atlantic Forest: lessons from aging human-modified 866 landscapes. Biological Conservation 143:2328-2340 
868

869

870

871

872

873

874

875

876

877

878

879

880

881

882

883

884

885

886

887

888

889

890

891

Terra, M.C.N.S, Mello, C.R., Mello, J.M. et al. 2017. Stemflow in a neotropical forest remnant: vegetative determinants, spatial distribution and correlation with soil moisture. Trees, DOI 10.1007/s00468-017-1634-3.

Terra, M.C.N.S., Mello, J.M., Mello, C.R., Santos, R.M., Nunes, A.C.R., Raimundo, M.R. 2015a Influência topo-edafo-climática na vegetação de um fragmento de Mata Atlântica na Serra da Mantiqueira, MG. Revista Ambiente \& Água, 10, 928-942.

Terra, M.C.N.S., Mello, J.M., Mello, C.R. 2015b. Relação Espacial do Carbono da Vegetação e Matéria Orgânica do Solo na Serra da Mantiqueira. Revista Floresta e Ambiente. http://dx.doi.org/10.1590/2179-8087.059713

Tomasella, J., Hodnett, M.G., Cuartas, L.A., Nobre, A.D., Waterloo, M.J., Oliveira, S.M., 2008. The water balance of an Amazonian micro-catchment: the effect of interannual variability of rainfall on hydrological behavior. Hydrological Processes, 22, 2133-2147. doi: 10.1002/hyp.6813.

Yin, Y., Wu, S., Zheng, D., Yang, Q. 2008. Radiation calibration of FAO56 PenmanMonteith model to estimate reference crop evapotranspiration in China. Agricultural Water Management, 95, 77-84. DOI: 10.1016/j.agwat.2007.09.002.

Wiekenkamp, I., Huisman, J.A., Bogena, H.R., Lin, H.S., Vereecken, H. 2016. Spatial and temporal occurrence of preferential flow in a forested headwater catchment. Journal of Hydrology, 534, 139-149. 
892

893 Zema, D.A., Lucas-Borja, M.E., Carrà, B.G., Denisi, P., Rodrigues, V.A., Ranzini, M., 894 Arcova, F.C.S., Cicco, V., Zimbone, S.M. Simulating the hydrological response of a 895 small tropical watershed (Mata Atlantica, Brazil) by the AnnAGNPS model. Science of 896 the Total Environment, 636, 737-750.

897

898 Zimmermann, B., Zimmermann, A., Scheckenbach, H.L., Schmid, T., Hall, J.S., van 899 Breugel, M. 2013. Changes in rainfall interception along a secondary forest succession 900 gradient in lowland Panama. Hydrological and Earth Systems Science 17, 4659-4670.

901

902

903

904

905

906

List of Tables

907 Table 1. Daily gross precipitation (P), canopy rainfall interception (C), and 908 evapotranspiration (ET) for AFMC according to the seasons of the studied hydrological 909 years.

\begin{tabular}{c|c|c|c|c}
\hline Hydrological Year & Season & P & C & ET \\
& & $\left(\mathrm{mm} \mathrm{d}^{-1}\right)$ & $\left(\mathrm{mm} \mathrm{d}^{-1}\right)(\mathrm{C} / \mathrm{P}, \%)$ & $\left(\mathrm{mm} \mathrm{d}^{-1}\right)$ \\
& & & & \\
\hline
\end{tabular}




\begin{tabular}{l|c|c|c|c}
\hline \multirow{3}{*}{$2009-2010$} & Wet & 10.24 & $2.14(20.9)$ & 4.84 \\
\cline { 2 - 5 } & Dry & 1.49 & $0.37(24.8)$ & 1.58 \\
\cline { 2 - 5 } & Hydrological year & 5.86 & $1.25(21.3)$ & 3.21 \\
\hline \multirow{3}{*}{$2010-2011$} & Wet & 13.82 & $2.87(20.8)$ & 5.09 \\
\cline { 2 - 5 } & Dry & 0.80 & $0.13(16.3)$ & 1.53 \\
\cline { 2 - 5 } & Hydrological year & 7.31 & & 3.31 \\
\cline { 2 - 5 } & & & & \\
\hline
\end{tabular}

910

911

912

913

914

915

916

917 Table 2. Streamflow, baseflow, and baseflow index (BFI) coefficient for seasons of the

918 studied hydrological years in AFMC.

\begin{tabular}{l|c|c|c|c}
\hline $\begin{array}{c}\text { Hydrological } \\
\text { year }\end{array}$ & Season & Streamflow & Base flow & BFI \\
& & $\left(\mathrm{mm} \mathrm{d}^{-1}\right)$ & $\left(\mathrm{mm} \mathrm{d}^{-1}\right)$ & \\
\hline & Wet season & 2.86 & 2.10 & 0.74 \\
\hline
\end{tabular}




\begin{tabular}{l|c|c|c|c}
\hline 2009-2010 & Dry season & 1.31 & 1.10 & 0.84 \\
\cline { 2 - 5 } & Hydrological year & 2.09 & 1.60 & 0.77 \\
\hline \multirow{3}{*}{$2010-2011$} & Wet season & 3.85 & 2.50 & 0.65 \\
\cline { 2 - 5 } & Dry season & & & 0.89 \\
& & & & 0.97 \\
\cline { 2 - 5 } & Hydrological year & 2.47 & 1.74 & 0.70 \\
\hline
\end{tabular}

919

920

921

922

923

924

925

926

927

928 Table 3. Multiple regressions for baseflow and overland flow in the AFMC as a function

929 of soil water storage (SWS) in different layers, evapotranspiration, and throughfall.

\begin{tabular}{c|c|c|c|c}
\hline Hydrologic Variable & $\begin{array}{c}\text { Explaining } \\
\text { variables }\end{array}$ & $\begin{array}{c}\text { Estimate } \\
\text { parameter }\end{array}$ & $p$-value $(t)$ & $\begin{array}{c}\text { Ajusted- } \\
\mathrm{R}^{2}\end{array}$ \\
\hline Streamflow (overland flow + & (Intercept) & 5.73593 & 0.7007 & 0.6197 \\
baseflow) & Throughfall $(\mathrm{mm})$ & 0.27284 & $3.11 \mathrm{e}-05^{* * *}$ & \\
\hline
\end{tabular}




\begin{tabular}{|c|c|c|c|c|}
\hline & SWS $20-60 \mathrm{~cm}$ & 0.31514 & $0.00622 * *$ & \\
\hline Overland flow & $\begin{array}{c}\text { (Intercept) } \\
\text { Throughfall }(\mathrm{mm}) \\
\text { SWS } 20-60 \mathrm{~cm} \\
\text { SWS 60-100 cm }\end{array}$ & $\begin{array}{c}-10.63396 \\
0.24029 \\
0.62341 \\
-0.50479\end{array}$ & $\begin{array}{c}0.37755 \\
2.25 \mathrm{e}-06^{* * *} \\
0.00435 * * \\
0.04583^{*}\end{array}$ & 0.7077 \\
\hline Baseflow & $\begin{array}{c}\text { (Intercept) } \\
\text { SWS 60-100 cm } \\
\text { Evapotranspiration }\end{array}$ & $\begin{array}{l}-9.8888 \\
0.19736 \\
0.34162\end{array}$ & $\begin{array}{c}0.457907 \\
0.011014 * \\
0.000433 * * *\end{array}$ & 0.4803 \\
\hline
\end{tabular}

930 Note: $p$-value $(t)$ means $p$-value of the $t$-test applied to the parameter: $*$ significant at 0.05 ; $* *$ significant 931 at $0.01 ; * * *$ significant at 0.001 .

932

933

934

935

936

937

938

939

940

941 Table 4. Variation in water storage in the entire AFMC $(\triangle \mathrm{AFMC})$, in unsaturated zone

$942\left(\Delta \mathrm{S}_{\text {soil }}\right)$, and estimated potential groundwater recharge (GS, for the end of the wet seasons)

943 in the studied hydrological years. 


\begin{tabular}{c|c|c|c|c}
\hline Hydrological year & Season & $\Delta$ AFMC & $\Delta \mathrm{S}_{\text {soil }}$ & GS \\
& & $(\mathrm{mm})$ & $(\mathrm{mm})$ & $(\mathrm{mm})$ \\
\hline \multirow{5}{*}{$2009-2010$} & Wet season & 461.3 & 57.5 & 403.8 \\
\cline { 2 - 5 } & Dry season & -258 & -88 & - \\
\cline { 2 - 5 } & Hydrological Year & 203 & - & - \\
\hline \multirow{7}{*}{$2010-2011$} & Wet season & 889.6 & 179.1 & 710.5 \\
\cline { 2 - 5 } & & & & - \\
\cline { 2 - 5 } & Dry season & -335.1 & -190 & - \\
\cline { 2 - 5 } & Hydrological year & 554.5 & - & \\
\hline
\end{tabular}

944

945

946

947

948

949

950

951

$952 \quad$ Figure captions 
953 Figure 1. Geographical location and instrumentation used for monitoring water balance 954 elements in the AFMC, Mantiqueira Range, Minas Gerais (MG) state, southeastern 955 Brazil.

956

957 Figure 2. Average water table depth between 2009 and 2011 in an AFMC neighboring 958 micro-catchment also located in the Lavrinha Creek Watershed as observed by Oliveira 959 (2014) (see the piezometers' location in Fig. 1).

960

Figure 3. Monthly gross precipitation, throughfall and its standard errors as observed in 962 the AFMC during the hydrological years of 2009-2010 and 2010-2011 (a) and average monthly gross precipitation and respective standard deviation as observed in the Lavrinha Creek Watershed from 2006 to 2012 (b).

965

Figure 4. Relationship between evapotranspiration modeled (ET) and evapotranspiration 967 from water balance $\left(\mathrm{ET}_{\mathrm{WB}}\right)$ during the dry periods in AFMC site (a), and comparison 968 between ET 8-day modeled and ET 8-day from MODIS (b, c).

Figure 5. Temporal behavior of the leaf area index (monthly) (a), evapotranspiration 971 (daily and monthly values) (b), air temperature (hourly, daily and monthly values) (c), and net radiation (daily and monthly values) in the AFMC throughout the studied period (2009 to 2011). 
974

975 Figure 6. Soil Water Storage dynamics (average and upper and lower limits calculated 976 based on the 25 locations for soil moisture measurement - Figure 1) throughout the 977 hydrological years from 2009 to 2011.

978

979 Figure 7. Classes of rainfall intensity frequency (a) and daily streamflow, base flow and 980 rainfall (b) throughout the hydrological years in the AFMC.

981

982 Figure 8. Daily water balance variation, potential groundwater recharge and daily rainfall 983 in the AFMC during the hydrological years of 2009/2010 and 2010/2011.

984

985

986

987

988 